\title{
BODY DONATION: AN ANATOMICAL GIFT TO HELP FUTURE GENERATIONS
}

Shiksha Jangde ${ }^{1}$

\section{HOW TO CITE THIS ARTICLE:}

Shiksha Jangde. "Body Donation: An Anatomical Gift to Help Future Generations". Journal of Evolution of Medical and Dental Sciences 2015; Vol. 4, Issue 41, May 21; Page: 7255-7257,

DOI: $10.14260 /$ jemds/2015/1053

\section{INTRODUCTION:}

\section{Dear Editor,}

"Body donation is the act of giving away one`s body after death without any conditions or rewards for the sake of education and research in medicine." 1

A sound knowledge of anatomy is essential from the beginning of a medical education and knowledge obtained through dissection of human body is an indispensable part of the education of health care professionals. It is the first step to become a doctor. Pool of source for cadaver used to be unclaimed bodies and few donated bodies. The Anatomy Act,,$^{2}$ provides for the supply of unclaimed bodies to teaching institutions and hospitals for the purpose of dissection and research work. With the mushrooming of medical Institutions in the country and need of human tissue for medical research and science is great, scarcity of bodies is felt all over the world. ${ }^{3,4}$ The situation is equally affected in India too. ${ }^{2}$ Too fulfill the requirement there came the ideology of voluntary body donation.

Voluntary whole body donations by generous individuals are relied upon as a resource to help physicians and other medical personnel complete their required learning, as they prepare themselves to provide for outstanding are for the living.

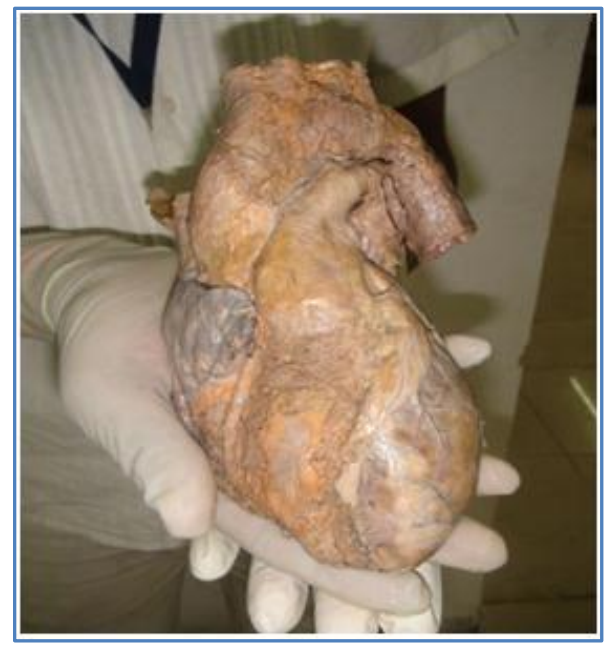

\section{Fig. 1: Gift your body to help future generations}

Although body donation is not for everyone, many are drawn to the ability to leave one last gift for humankind. A very tangible and selfless gift.

A recently published study investigated the motivations for body donation to science. The majority of donors (93\%) stated that the desire to be useful after death was the main criterion in their decision to become a body donor and $49 \%$ of donors were motivated to express their gratitude for life and health and to medical professions. ${ }^{5}$ Since few years due to awareness of body donation for 
research purpose, the medical colleges are getting donated bodies. Students and staff treat each donation with the utmost respect and dignity. ${ }^{6}$

\section{Every year our institute also receive many donated bodies and numbers of peoples submit} body donation form. They believes:

1. Body donation will help others by training the doctors of the future.

2. I want to help people after I've died.

3. It's an extra plus point that I can help people when I'm still on earth.

4. We didn`t want to be buried and we didn`t have strong family ties, we wanted our bodies to go to a useful purpose.

5. I want, when I die, the spirit will go to heaven and the body will stay in the earth to help future generation.

CONCLUSION: Voluntary body donation program is running successfully in most of the countries and many institutes in our country to catering the need of their institute for cadavers. Despite this, body donation remains suboptimal worldwide. In India, most citizens are not willing to become body donors. There is strong need to popularize the message to common masses by stating the importance of body donation. Efforts to encourage discussions about whole body donation should be implemented in order to improve current low levels of donation. The development of consciousness of the human being in the whole body donation lies in their social responsibilities.

Death is an inevitable part of life. When faced with options on what to do with your body after you have lived out your last breath, please consider whole body donation and help to support medical research, education and training that will improve patient care immediately and in the future.

ACKNOWLEDGEMENT: I really acknowledge all who had donated their bodies.

\section{REFERENCES:}

1. Tatsuo SAKAI (2008), Body donation: An act of love supporting anatomy education. The journal of the Japan medical association. 51 (1): $39-45$.

2. Ajita R, Singh YI. Body donation and its relevance in anatomy learning- a review. JASI 2007; 56 (1): $44-47$.

3. Sehirli US, Saka E, Sarikaya O. Attitudes of Turkish anatomists towards cadaver donation. Clin Anat. 2004; 17 (8): 677-781.

4. Boulware LE, Ratner LE, Cooper LA, LaVeist TA, Powe NR. Whole body donation for medical science: a population based study. Clinical Anatomy, 2004; 17 (7): 570-577.

5. Bolts, Venbrux E, Eisinga R, Kuks JB, Veening JG, Gerrits PO. Motivation for body donation to science: more than an altruistic act. Ann. Anat 2010; 192: 70-74.

6. Gorlick A. Body donors give "ultimate gift" to medical students. The Standard-Times, 2004 Sep 19. 


\section{AUTHORS:}

1. Shiksha Jangde

\section{PARTICULARS OF CONTRIBUTORS:}

1. Assistant Professor, Department of Anatomy, Chhattisgarh Institute of Medical Science, Bilaspur, Chhattisgarh.

FINANCIAL OR OTHER

COMPETING INTERESTS: None
NAME ADDRESS EMAIL ID OF THE CORRESPONDING AUTHOR:

Dr. Shiksha Jangde,

C/o. Shri. K. R. Jangde, MIG -60, Nehru Nagar, Bilaspur-495001, Chhattisgarh, India.

E-mail: drshiksha2013@gmail.com

Date of Submission: 24/04/2015. Date of Peer Review: 25/04/2015. Date of Acceptance: 13/05/2015. Date of Publishing: 21/05/2015. 